\title{
Article \\ Structural and Chemical Properties of Geopolymer Gels Incorporated with Neodymium and Samarium
}

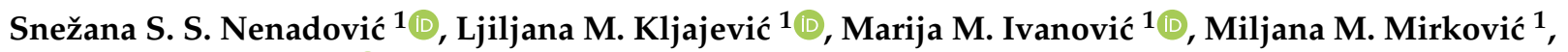 \\ Nadežda Radmilović ${ }^{2}$, Lazar Z. Rakočević ${ }^{2}$ and Miloš T. Nenadović ${ }^{2, *}$ \\ 1 Department of Materials, Vinča Institute of Nuclear Sciences, National Institute of the Republic of Serbia, \\ University of Belgrade, Mike Petrović Alasa 12-14, Vinča, 11000 Belgrade, Serbia; \\ msneza@vin.bg.ac.rs (S.S.S.N.); lijljana@vin.bg.ac.rs (L.M.K.); marija@vin.bg.ac.rs (M.M.I.); \\ miljanam@vin.bg.ac.rs (M.M.M.) \\ 2 Department of Atomics Physics, Vinča Institute of Nuclear Sciences, National Institute of the Republic of \\ Serbia, Mike Petrović Alasa 12-14, Vinča, 11000 Belgrade, Serbia; nadezdas@vin.bg.ac.rs (N.R.); \\ lazarrak@gmail.com (L.Z.R.) \\ * Correspondence: milosn@vin.bg.ac.rs
}

Citation: Nenadović, S.S.S.; Kljajević, L.M.; Ivanović, M.M.; Mirković, M.M.; Radmilović, N.; Rakočević, L.Z.; Nenadović, M.T. Structural and Chemical Properties of Geopolymer Gels Incorporated with Neodymium and Samarium. Gels 2021, 7, 195. https://doi.org/10.3390/gels7040195

Academic Editor: David Díaz Díaz

Received: 30 September 2021

Accepted: 29 October 2021

Published: 3 November 2021

Publisher's Note: MDPI stays neutral with regard to jurisdictional claims in published maps and institutional affiliations.

Copyright: (C) 2021 by the authors. Licensee MDPI, Basel, Switzerland. This article is an open access article distributed under the terms and conditions of the Creative Commons Attribution (CC BY) license (https:// creativecommons.org/licenses/by/ $4.0 /)$.

\begin{abstract}
The present work was focused on doping of $1 \%$ and $5 \%$ both of $\mathrm{Nd}_{2} \mathrm{O}_{3}$ and $\mathrm{Sm}_{2} \mathrm{O}_{3}$ in geopolymer gels. One of the main goals was to determine the influence of the behavior of $\mathrm{Nd}$ and $\mathrm{Sm}$ as dopants and structural nanoparticles changes of the final geopolymer formed. It is shown that the disorder formed by alkali activation of metakaolin can accommodate the rare earth cations $\mathrm{Nd}^{3+}$ and $\mathrm{Sm}^{3+}$ into their aluminosilicate framework structure. The main geopolymerization product identified in gels is Al-rich (Na)-AS-H gel comprising $\mathrm{Al}$ and $\mathrm{Si}$ in tetrahedral coordination. $\mathrm{Na}^{+}$ions were balancing the negative charge resulting from $\mathrm{Al}^{3+}$ in tetrahedral coordination. The changes in the structures of the final product (geopolymer $/ \mathrm{Nd}_{2} \mathrm{O}_{3} ; \mathrm{Sm}_{2} \mathrm{O}_{3}$ ), has been characterized using X-ray diffraction (XRD), Fourier transform infrared spectroscopy (FTIR), X-ray photoelectron spectroscopy (XPS) and transmission electron microscopy (TEM) analysis with energy dispersive spectrometry (EDS). Nucleation at the seed surfaces leads to the formation of phase-separated gels from rare earth phase early in the reaction process. It is confirmed that $\mathrm{Nd}$ and $\mathrm{Sm}$ have been shown to form unstable hydroxides $\mathrm{Nd}(\mathrm{OH})_{3}$ and $\mathrm{Sm}(\mathrm{OH})_{3}$ that are in equilibrium with the corresponding oxides.
\end{abstract}

Keywords: geopolymer gel; rare earth; $\mathrm{Nd}_{2} \mathrm{O}_{3} ; \mathrm{Sm}_{2} \mathrm{O}_{3}$; thermodynamic parameters; DRIFT; XRD; XPS; TEM

\section{Introduction}

A geopolymers are well-known alkali aluminosilicate cement materials that can have superior mechanical, chemical and thermal properties when compared to other Portlandbased cements, showing significantly lower levels of $\mathrm{CO}_{2}$ production [1]. Geopolymers form a structure closed cage-like cavity together with combination of ring molecules that can separate metal ions or other toxic substances and catch them inside the cavity. Despite that, some metal cations can even participate in the geopolymerization reaction [2,3]. Research to date has shown a lot of results in field of toxic heavy metals treatment by immobilization into alkali activated structure [4-12].

Rare earth elements (REEs) have become increasingly important metals used in modern technology and potential applications. However, their increasing use in the industrial sector, medicine and agriculture over the last few decades has provided them with the title of "new pollutants" [13]. In the past few years, modification with some rare earth (RE) metals has shown to be an efficient method of improving the photocatalytic properties of $\mathrm{TiO}_{2}$ and broadening its absorption band within the solar spectrum [14,15]. Doped titania gels are prepared where presence of neodymium stabilizes the amorphous phase of the sample up to higher temperatures $\left(400^{\circ} \mathrm{C}\right)$ as compared to the other one containing 
samarium [16]. It is also confirmed that $\mathrm{Sm}^{3+}$ ions increase the surface area but also enhance the photocatalytic activity under UV or solar light irradiation on Sm-doped $\mathrm{TiO}_{2}$ [16-19]. With reference to organic dyes, it was established that the presence of Sm is highly effective against Methyl orange [20]. Samarium has been studied extensively as a dopant in a wide number of host materials because of its chemical properties and the considerable modification on the properties of the host that are measured when even small concentrations of samarium are present. Physical properties of glass samples can be improved by the addition of different modifiers between the other rare earth oxides $\left(\mathrm{Gd}_{2} \mathrm{O}_{3}, \mathrm{Sm}_{2} \mathrm{O}_{3}\right.$, etc.) [21]. Rare earth oxide modifiers showed a significant improvement over glass systems. Gafara et al., 2020 investigated the structure and properties of Nd-modified Bi-Sr-borate glass, i.e., the effect of $\mathrm{Nd}_{2} \mathrm{O}_{3}$ addition on Bi-Sr-borate glasses for their possible applications in many aspects [22].

Rare earth oxides have been broadly utilized in different research areas due to their unique and interesting properties. Samarium oxide $\left(\mathrm{Sm}_{2} \mathrm{O}_{3}\right)$ is one of the promising candidate materials among rare earth oxides because of some outstanding properties such as large conduction offset with $\mathrm{Si}$, high thermal stability, small frequency dispersion and low trapping rates [23,24]. $\mathrm{Sm}_{2} \mathrm{O}_{3}$ is also predicted to be thermodynamically stable on $\mathrm{Si}$ substrates [25]. Neodymium oxide $\left(\mathrm{Nd}_{2} \mathrm{O}_{3}\right)$ was selected for electronic applications not only because of its high $\mathrm{k}$ but also good step coverage and good dielectric strengths [26]. In accordance with the above, samarium and neodymium oxides are important rare earth materials because of their suitability for optical, ceramic, solar cells, nanoelectronics, semiconductors, sensors and catalytic applications [27]. However, the risks of REE pollution due to mining and processing as well as from the improper disposal of materials containing these compounds could potentially lead to elevated levels within the environment. In addition, the processing of REE-rich monazite rocks for the production of phosphate fertilizers and the subsequent applications of these fertilizers could further elevate REE soil concentrations, especially in agricultural areas [22-24]. Sneller et al. [25] reported that approximately 85 tons of neodymium $(\mathrm{Nd})$ were released into the environment from phosphate fertilizer production in the Netherlands in 1994. Slooff et al. [26] reported that industrial emissions in air and water due to fertilizer production in the Netherlands can contain over $500 \mathrm{mg} / \mathrm{kg}$ of REEs. Petroleum refining processes can release similar amounts of REEs into the environment [26]. Studies have indicated that REEs can be absorbed by plants due to the similar ionic radii that they share with calcium $[27,28]$. As a result, REEs may replace calcium molecules in a number of physiological processes involving proteins and enzymes, including root growth, photosynthesis and flowering [28,29]. One of the potential ways to reduce the harmful impact of the excessive amount of REE present on plants, and thus on the rest of the living world, is their immobilization into a geopolymer structure. There are reports on the preparation of geopolymers with rare earth tailing, which is a specific tailing containing high content of heavy metals, and they propose a new scheme of disposing of the rare earth tailing through fixation during geopolymerization reaction, which could reduce the risk of secondary pollution caused by long-term leaching of heavy metals on condition that direct storage in tailings ponds [21].

One of the challenges is the fact that, despite a large number of studies and increasing attention about geopolymers, they are not fully elucidated, and the process of geopolymerization and the structure itself are still not well understood, given the diversity of precursors that can serve as a basis for obtaining these types of materials.

The focus of the present work is to pay more attention to the synthesis as well as the structural and chemical properties of the obtained geopolymer samples.

Ivanovic et al. examined the thermodynamic parameters (viscosity, density, refractive index, velocity of sound) of the alkaline activator and examined the influence on the synthesis of geopolymers [30]. It was confirmed that, with the knowledge of thermodynamic parameters, there is a better understanding of the first phase of gel formation of geopolymer structure. In previous research by Nenadović et al. [31], Kljajević et al. [32] and Ivanović et al. [33], the synthesis and structure of geopolymer material, the influence 
of aluminosilicate matrix and alkali activator change were monitored. Materials with $12 \mathrm{M}$ $\mathrm{NaOH}$ are the most common subjects, so the aim of this study is to examine the effect of $\mathrm{Nd}$ and $\mathrm{Sm}$ in the form of oxide incorporation in the first phase of gelation of the geopolymer structure. In addition to the thermodynamic parameters of the alkaline activator $12 \mathrm{M}$ $\mathrm{NaOH}$, the highest influence on the synthesis of geopolymer materials was examined, which is the reason for choosing the incorporation of $\mathrm{Nd}$ and $\mathrm{Sm}$ into the geopolymer material synthesized with $12 \mathrm{M} \mathrm{NaOH}$.

\section{Results and Discussion}

\subsection{Thermodynamic Parameters of Alkaline Activator}

Densities, refractive index and sound velocity of alkaline activator were determined at the temperature range from 15 to $60^{\circ} \mathrm{C}$. This temperature range covers the process of geopolymerization. Based on the results shown in Figure 1a-c, one can see that, for all tested systems, changes with temperature followed the usual behavior observed in liquid systems; that is, they decrease with increasing temperature due to the liquid's thermal expansion. Such observation may be attributed to the diminishing intermolecular forces in the liquid brought about by the thermal expansion of the liquid and the increasing velocities of the molecules (or ions) at higher temperatures.

In previous work by Ivanovic et al. [30], velocity of sound values shows a small increase with increasing temperature for solutions with lower $\mathrm{NaOH}$ concentration, which may be an indicator of increased ion mobility in solution. Since the changes during heating of the alkaline activator are in the range of $15-60{ }^{\circ} \mathrm{C}$ below $2.0 \%$ when it comes to density and refractive index, and since the velocity of sounds is slightly above $3.0 \%$, this indicates the thermodynamic stability of the activator leading to dissolution of the initial aluminosilicate types and creation of a new $\mathrm{Na}$-aluminosilicate gel structure of geopolymer samples.

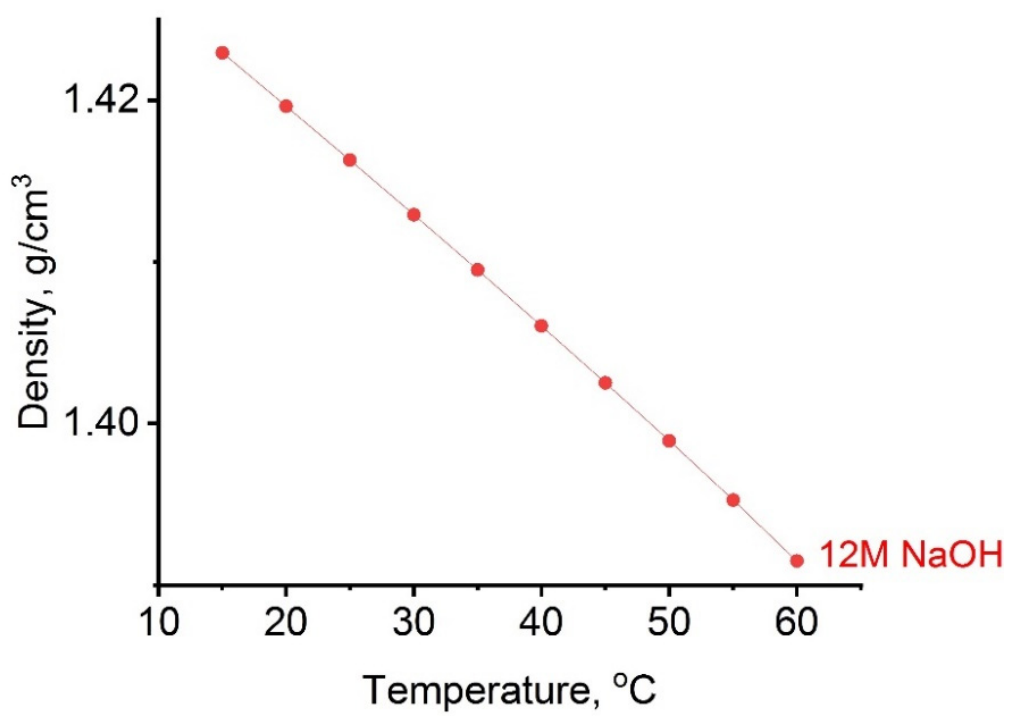

(a)

Figure 1. Cont. 


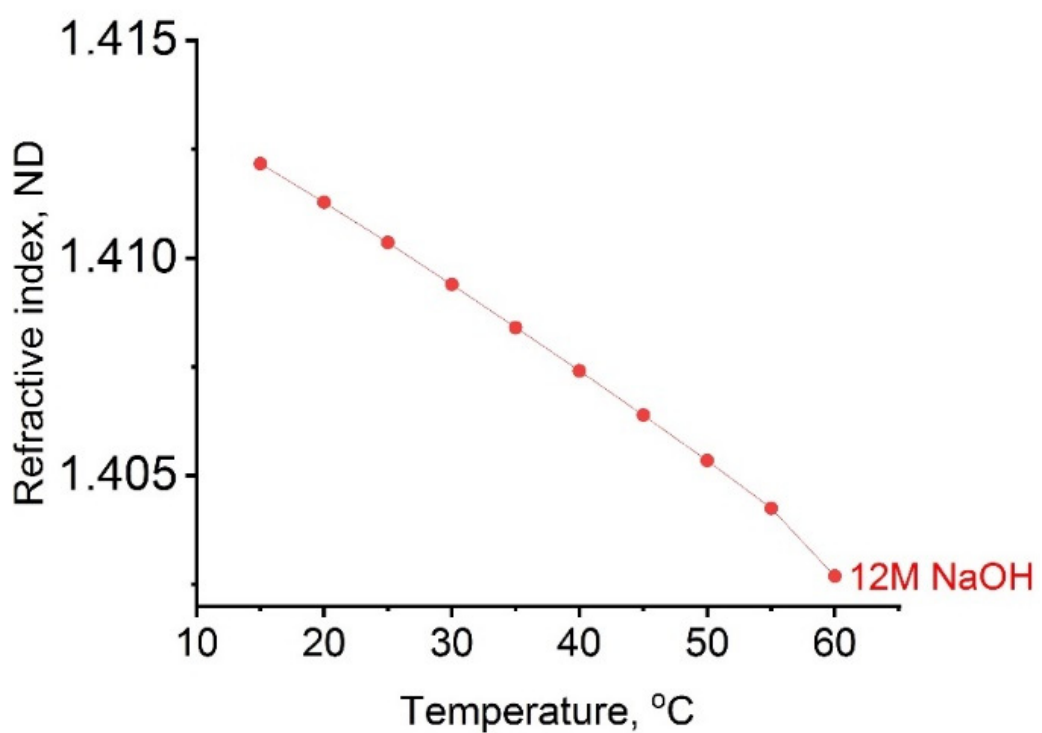

(b)

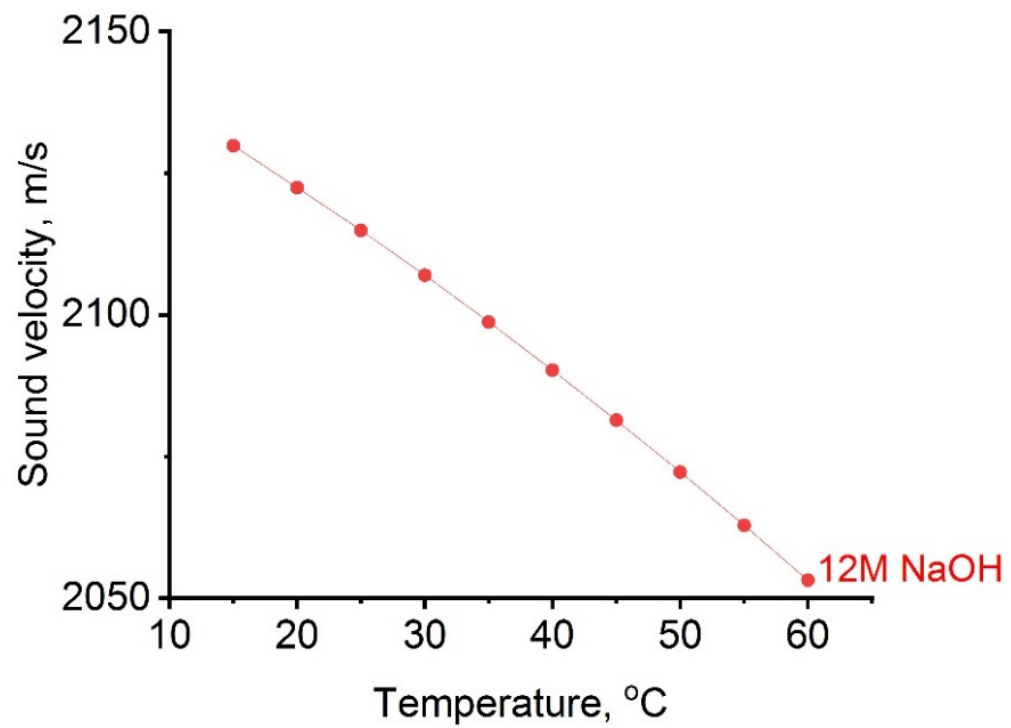

(c)

Figure 1. Influence of temperature on: (a) density, (b) refractive index, (c) velocity of sound on alkaline activator.

\subsection{Structural Analysis}

DRIFT data provided information regarding the energy of bond vibrations that occurred within the sample, and as such could distinguish between Si-O-Si and Si-O-Al bonds and allow observation of the location of nonbridging oxygen sites [34] and the presence of carbonate species, which may not be readily apparent in the solid-state XPS data. Figure 1 shows the DRIFT spectra for geopolymer samples doped with 1.0 and $5.0 \mathrm{wt} . \%$ of two rare earth oxides $\mathrm{Sm}_{2} \mathrm{O}_{3}$ and $\mathrm{Nd}_{2} \mathrm{O}_{3}$, denoted as GPE1 and GPE5 ( $\mathrm{E}$ is $\mathrm{Nd}$ or $\mathrm{Sm}$ ), respectively. The DRIFT spectrum for GPNd1 and GPNd5 (Figure 2a) exhibits a high intensity band at $1090 \mathrm{~cm}^{-1}$ that is assigned to asymmetric stretching of Si-O-T bonds [28,32,35-41] (where T $=\mathrm{Al}$ or $\mathrm{Si}$ in tetrahedral coordination) and a low-intensity band at $810 \mathrm{~cm}^{-1}$ that is assigned to symmetric stretching of Si-O-T bonds [41]. The bands at $\sim 460 \mathrm{~cm}^{-1}$ can be related to the Si-O-Si bending mode, and reflectance at $560 \mathrm{~cm}^{-1}$ can be attributed to the Si-O-Al vibrations. The bands at $690 \mathrm{~cm}^{-1}$ can be attributed to the Si-O-Si symmetric stretching vibrational mode. Si-O banding vibrations are responsible for the bands occurring at 
$793 \mathrm{~cm}^{-1}$ (corresponds to quartz). The reflectance at $923 \mathrm{~cm}^{-1}$ corresponds to Si-O bending vibrations [41]. It has been known that the peaks located at about $3444 \mathrm{~cm}^{-1}$ and $1634 \mathrm{~cm}^{-1}$ correspond to the stretching and contracting vibrations of -OH in water [42-44]. The tense peaks of $1090 \mathrm{~cm}^{-1}, 810 \mathrm{~cm}^{-1}$ and $465 \mathrm{~cm}^{-1}$ in geopolymers are caused by vibration of $\mathrm{Si}-\mathrm{O}-\mathrm{Si}, \mathrm{Al}-\mathrm{O}$ and O-Si-O, respectively [45], revealing that the geopolymer contains a large amount of active $\mathrm{Si}$ and $\mathrm{Al}$ components. The peaks $1452 \mathrm{~cm}^{-1}$ in geopolymers were related to the symmetrical vibration of the $\mathrm{O}-\mathrm{C}-\mathrm{O}$ in $\mathrm{CO}_{3}{ }^{2-}[46,47]$.

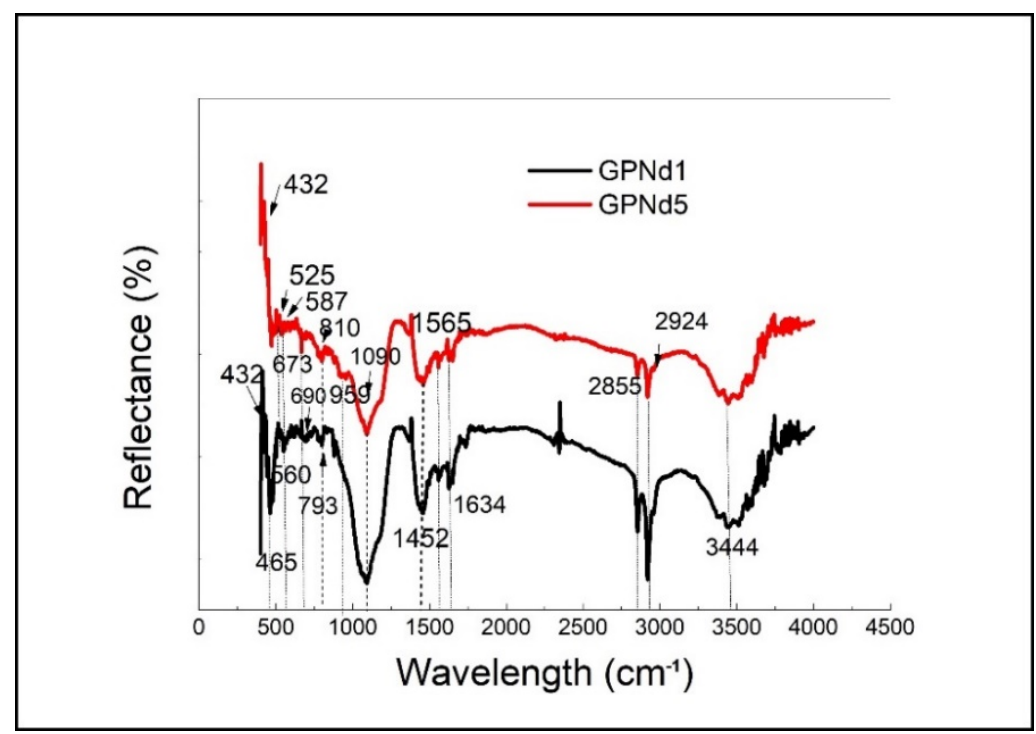

(a)

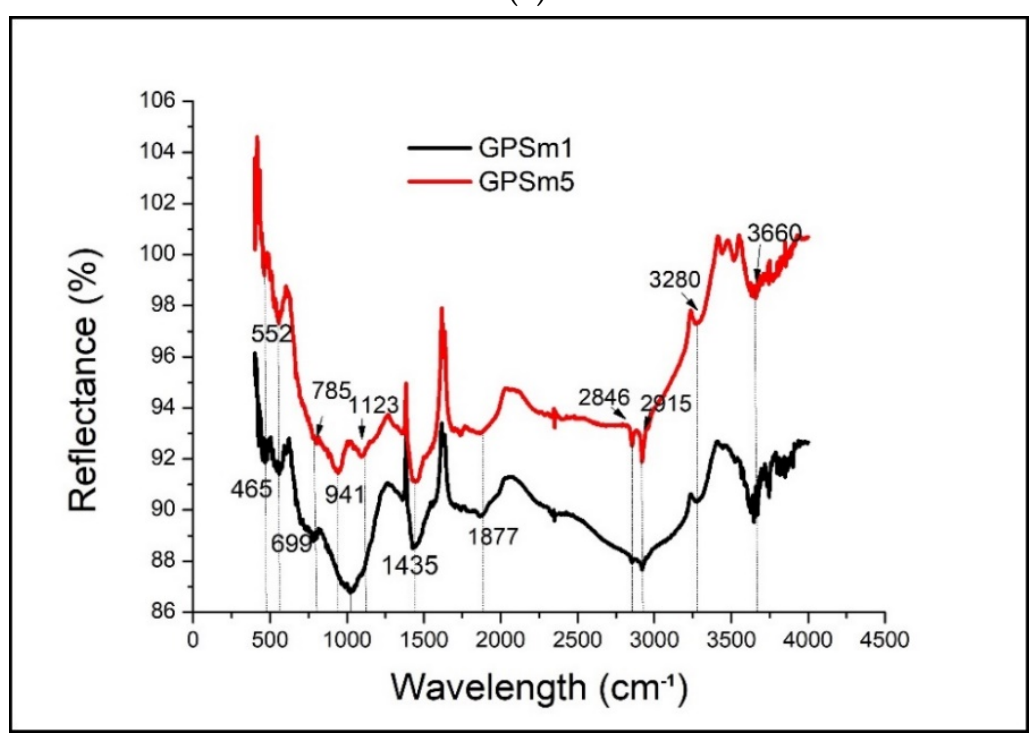

(b)

Figure 2. DRIFT spectra of: (a) GPNd and (b) GPSm.

The peaks at $432 \mathrm{~cm}^{-1}$ and $525 \mathrm{~cm}^{-1}$ correspond to the characteristic $\mathrm{Nd}-\mathrm{O}$ vibrations of $\mathrm{Nd}_{2} \mathrm{O}_{3}$ nanoparticles [48]. The incorporated $\mathrm{Nd}$ samples exhibit the presence of bands at $587 \mathrm{~cm}^{-1}$ and $673 \mathrm{~cm}^{-1}$ and also correspond to $\mathrm{Nd}-\mathrm{O}$ vibrations of $\mathrm{Nd}$ oxides [49]. The spectrum has an enormous number of weak absorption peaks, which indicates weak O-H vibrations and sharp peaks for strong $\mathrm{O}-\mathrm{H}$ vibrations. Moreover, reflectance at $1565 \mathrm{~cm}^{-1}$ is new in the geopolymer system and is possible to connect with the $\mathrm{Nd}_{2} \mathrm{O}_{3}$ structure.

The existence of bands at $525 \mathrm{~cm}^{-1}$ and $685 \mathrm{~cm}^{-1}$ was observed in geopolymer samples with $5 \%$ of $\mathrm{Sm}_{2} \mathrm{O}_{3}$ (Figure $2 \mathrm{~b}$ ); these two bands could be attributed to the stretching 
vibration of $\mathrm{Sm}_{2} \mathrm{O}_{3}$ species and bending vibration of $\mathrm{Sm}-\mathrm{O}-\mathrm{H}$ groups, respectively [50]. A noticeable band at $785 \mathrm{~cm}^{-1}$ due to the stretching vibration of $\mathrm{Sm}^{3+}-\mathrm{O}$ groups in $\mathrm{Sm}_{2} \mathrm{O}_{3}$ phase is observed in the case of GPSm5. An intense wide band is observed around $1028 \mathrm{~cm}^{-1}$ due to $\mathrm{Sm}^{3+}$ (stretching vibration) [51] ion doping in the prepared sample. This band is wide and most likely overlaps with the Si-O band, which belongs to the basic geopolymer structure found in this range [31]. The presence of samarium oxide in the geopolymer samples improves the optical properties of sample.

The peaks shown in Figure 2b corresponding to $\mathrm{H}-\mathrm{O}-\mathrm{H},-\mathrm{OH}, \mathrm{Si}-\mathrm{O}-\mathrm{T}$ ( $\mathrm{T}-\mathrm{Si}, \mathrm{Al}$ ), Si-O, $\mathrm{O}-\mathrm{C}-\mathrm{O}$, and the presence of the organic phase of geopolymer structure of the samples GPSm1 and GPSm5 are 3280, 3660, 465, 552, 699, 1028, 1123, 1435, 2846, $2915 \mathrm{~cm}^{-1}$.

\subsection{XRD Analysis}

As can be seen from the results of X-ray diffraction in both samples presented in Figure $3 a, b$, the existence of crystalline albite quartz and some muscovite peaks is evident, indicating semicrystalline structural formation. During geopolymerization process and synthesis reaction, aluminosilicate mineral phases stay unchanged. Sample GP1Sm is characterized by significantly lower intensities of Sm peaks in contrast to sample GP5Sm, where peaks are significantly more intense and sharper. The increase in the intensity and sharpness of the peaks in GP5Sm indicate that the contribution of Sm and its incorporation into the geopolymer matrix is higher, which is in correlation with the synthesis procedure.
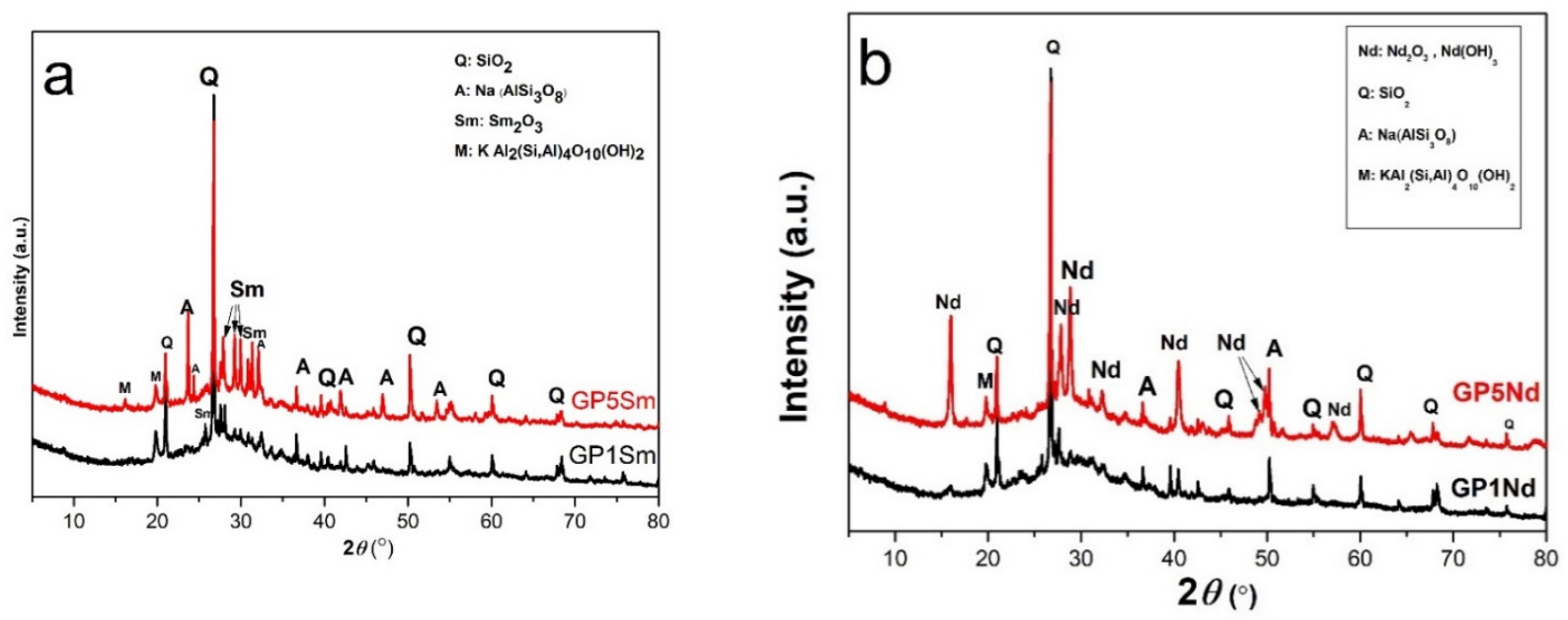

Figure 3. XRPD diffractograms of samples: (a) GP1Sm and GP5Sm and (b) GP 1Nd and GP5Nd.

It is also evident, by comparing the diffractograms, that the peaks are slightly shifted to the left, which indicates the incorporation of Sm into the primary geopolymer gel. Increasing of intensities of Sm peaks on presented diffractograms is related to higher mass volume addition of Sm during the synthesis, which is unequivocally confirmed by obtained XRD results. Based on XRD results presented in Figure $3 \mathrm{~b}$, it is clear that $\mathrm{Nd}$ in geopolymer matrix is represented as joint contribution of oxide and hydroxide in geopolymer gel. By comparing the results of XRD analysis in Figure 3b, it is clear that the GP5N sample with a higher percentage mass volume of neodymium addition in the synthesis process reveals peaks with significantly higher intensity, indicating confirmation that a larger amount of $\mathrm{Nd}$ is incorporated in the geopolymer structure. As in the previous samples, the main crystalline phases of the geopolymer remain unchanged. A high background in the range of 10 to $40^{\circ} 2 \theta$ indicates the formation of a primary geopolymer matrix in all samples.

\subsection{XPS Analysis}

Figure 4a presents a survey spectrum of a geopolymer doped with $1 \%$ neodymium. The most dominant peaks observed are O1s and C1s, on the basis of which further detailed analysis of the spectrum was performed. Since it is an aluminosilicate material, the presence 
of $\mathrm{Al} 2 \mathrm{p}$ and $\mathrm{Si} 2 \mathrm{p}$ spectral lines is observed in the low-energy part of te spectrum. In the high-energy part of the spectrum (about $1000 \mathrm{eV}$ ), a complex peak of the neodymium $\mathrm{Nd}$ $3 \mathrm{~d}$ spectral line appears.
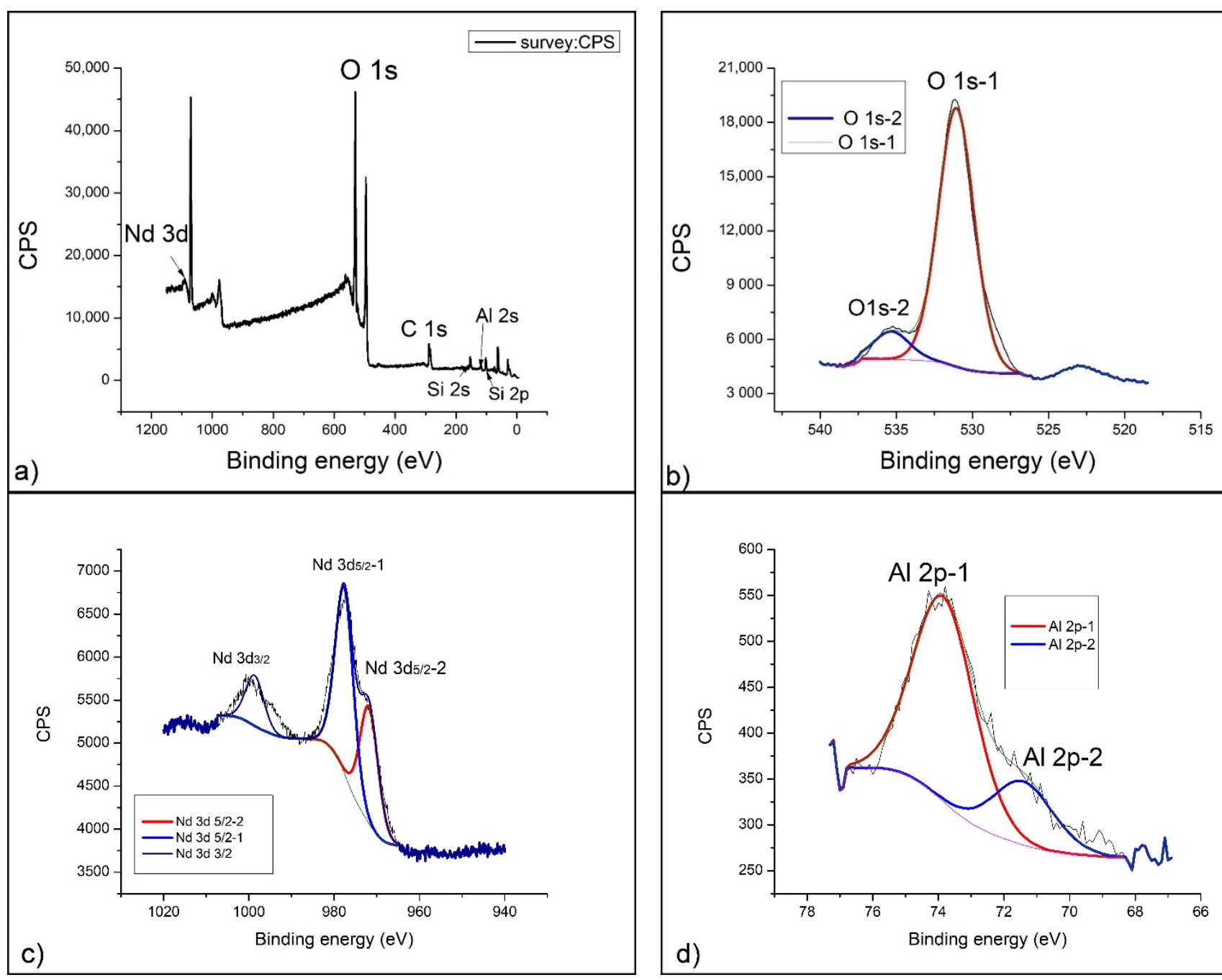

b)
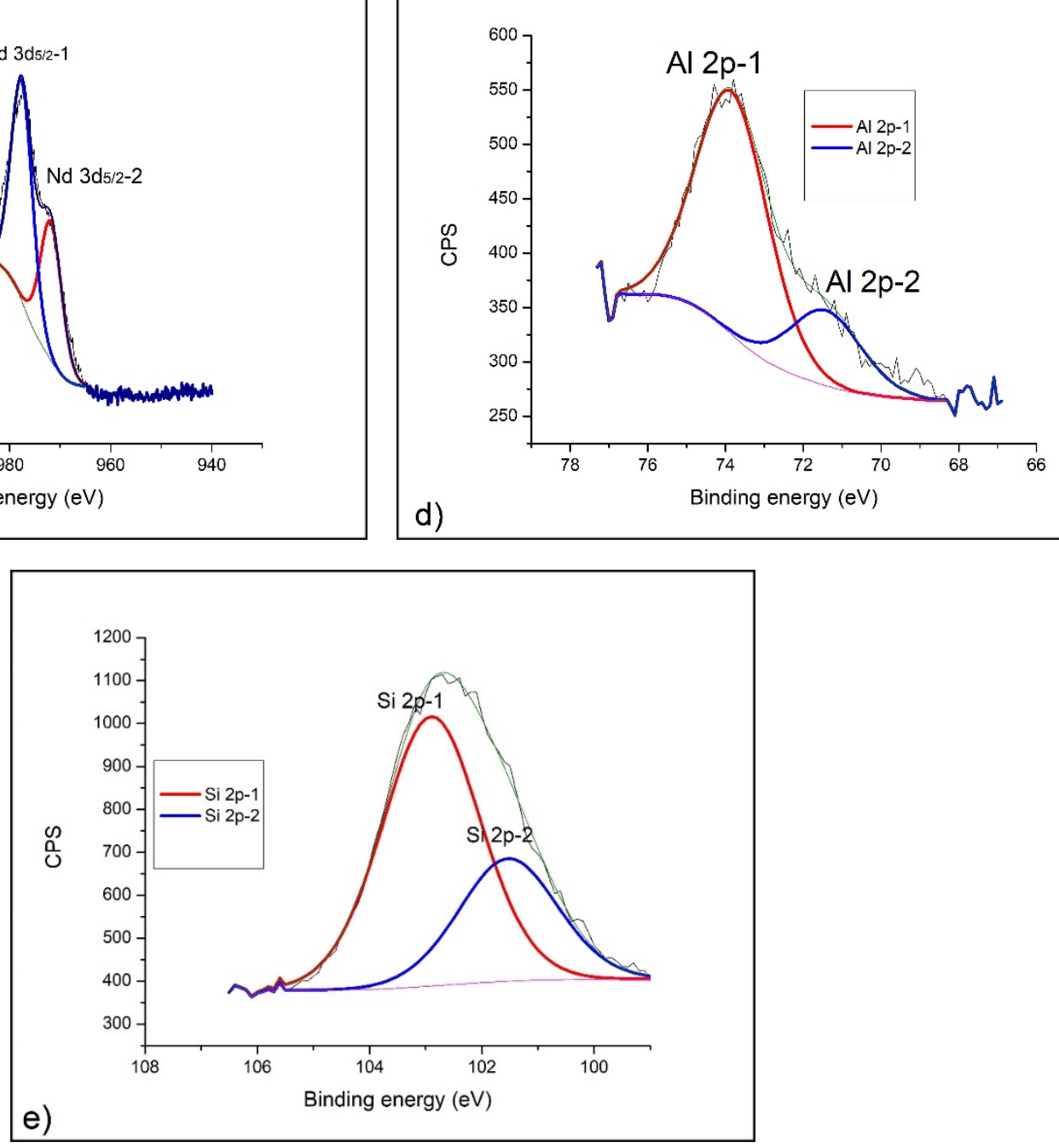

Figure 4. XPS spectrum of GP with 1\% Nd: (a) Survey spectrum, (b) O 1s, (c) Nd 3d, (d) Al 2p and (e) Si 2p. 
Figure $4 \mathrm{~b}$ gives a clearer insight into the way of oxygen binding by the detailed spectrum, on which the deconvolution of the $\mathrm{O}$ 1s spectral line was performed. The deconvolution of the oxygen spectral line results in two contributions: The first, more dominant $(\mathrm{O} 1 \mathrm{~s}-1)$, is located at $531.2 \mathrm{eV}$ of the binding energy and basically represents the dominant phase of $\mathrm{Al}_{2} \mathrm{O}_{3}$. The second contribution, of lower intensity $(\mathrm{O} 1 \mathrm{~s}-2)$, is at $535.4 \mathrm{eV}$ of binding energy, and since it is at the end of the energy range of the oxygen spectral line, it belongs to complex aluminosilicate compounds, which, after alkaline activation, are formed as side products $\left(\mathrm{CaAl}_{2} \mathrm{O}_{4}\right.$ and $\left.\mathrm{SiAl}_{2} \mathrm{O}_{4}\right)$.

Neodymium (III) oxide, which was used for doping geopolymers, was incorporated into the geopolymer structure forming two dominant contributions of the $\mathrm{Nd} 3 \mathrm{~d}$ spectral line (Figure 4c). The first and more dominant contribution is located at a binding energy of $998.9 \mathrm{eV}(\mathrm{Nd} 3 \mathrm{~d} \mathrm{5/2-1)}$ and corresponds to the existence of an equilibrium mixture of $\mathrm{Nd}(\mathrm{OH})_{3}+\mathrm{Nd}_{2} \mathrm{O}_{3}$, which was formed by alkaline activation. Since hydroxides of rare earths (including neodymium) are not stable, another contribution of the spectral line on $977.9 \mathrm{eV}(\mathrm{Nd} 3 \mathrm{~d} 5 / 2-2)$ occurs [52]. It belongs to pure $\mathrm{Nd}_{2} \mathrm{O}_{3}$, which was the starting material. By quantitative analysis of the areas under the curves, we can conclude that the amount of reacted $\mathrm{Nd}_{2} \mathrm{O}_{3}$ is about two-thirds of the total amount added. One-third of the $\mathrm{Nd}_{2} \mathrm{O}_{3}$ did not react with the alkaline activator at all and remained in the form of the starting oxide.

The detailed spectrum of the aluminum $2 \mathrm{p}$ line further confirms the existence of $\mathrm{Al}_{2} \mathrm{O}_{3}$ at a binding energy of $73.9 \mathrm{eV}-\mathrm{Al} 2 \mathrm{p}-1$ (Figure $4 \mathrm{~d}$ ). This more dominant part of amorphous $\mathrm{Al}_{2} \mathrm{O}_{3}$ is complemented by the less present crystalline $\mathrm{Al}_{2} \mathrm{O}_{3}$, which is located at a binding energy of $71.4 \mathrm{eV}(\mathrm{Al} 2 \mathrm{p}-2)$ and represents the alpha phase crystal structure [53]. The total ratio of amorphous and crystalline $\mathrm{Al}_{2} \mathrm{O}_{3}$ is $4: 1$. This is certainly a consequence of the process of alkaline activation, which has a nonselective effect on the starting substances in the geopolymerization reaction.

By detailed analysis of the $\mathrm{Si} 2 \mathrm{p}$ spectrum, we can confirm the existence of complex structures within the geopolymer. In Figure 4e, one can observe that, at $102.9 \mathrm{eV}$ (Si 2p-1), the $\mathrm{SiO}_{2}$ and $\mathrm{Al}_{2} \mathrm{OSiO}_{4}$ phases dominate, with a smaller contribution on $101.5 \mathrm{eV}$ (Si 2p-2) corresponding to the molecular sieve (zeolite $3 \mathrm{~A}$ ) of $\mathrm{NaAl}_{2} \mathrm{SiO}_{4}$ [54]. The chemical composition of the geopolymer formed in this case corresponds to the position of the spectral line for zeolite $3 \mathrm{~A}$, only in this case, a predominantly amorphous structure is obtained.

In the case of the geopolymer doped with $5 \%$ neodymium, the appearance of the $\mathrm{Nd}$ $4 \mathrm{~d}$ spectral line together with the dominant $\mathrm{Nd} 3 \mathrm{~d}$ is observed on the survey spectrum, which is analyzed in detail (Figure 5a). The appearance of the $\mathrm{Nd} 4 \mathrm{~d}$ line in the low-energy part of the spectrum is definitely a consequence of the dopant concentration, i.e., amounts of neodymium present in the geopolymer. The positions of $\mathrm{O} 1 \mathrm{~s}$ and $\mathrm{C} 1 \mathrm{~s}$ on the survey spectrum are the same as in GP with $1 \% \mathrm{Nd}$.

Unlike GP $1 \% \mathrm{Nd}$, this sample shows a more complex spectral line $\mathrm{O} 1 \mathrm{~s}$, where deconvolution yields three contributions. The most dominant peak occurring at $531.8 \mathrm{eV}$ $\mathrm{O} 1 \mathrm{~s}-1$ is amorphous $\mathrm{Al}_{2} \mathrm{O}_{3}$. The second most common is the contribution of $\mathrm{O} 1 \mathrm{~s}-2$ to $529.5 \mathrm{eV}$, and it is related to crystalline $\mathrm{Al}_{2} \mathrm{O}_{3}$. In Figure $5 \mathrm{~b}$, it can be determined that the ratio of amorphous to crystalline $\mathrm{Al}_{2} \mathrm{O}_{3}$ is $2: 1$. The difference in relation to GP $1 \% \mathrm{Nd}$ is the appearance of the crystalline phase $\mathrm{Al}_{2} \mathrm{O}_{3}$ in addition to the dominant amorphous one. At a binding energy of $535.4 \mathrm{eV}(\mathrm{O} 1 \mathrm{~s}-3)$, as in the previous case, a clear presence of $\mathrm{CaAl}_{2} \mathrm{O}_{4}$ and $\mathrm{SiAl}_{2} \mathrm{O}_{4}$ as a side product of geopolymerization is confirmed.

Detailed analysis of the $\mathrm{Nd} 3 \mathrm{~d}$ spectral line in the case of GP $5 \% \mathrm{Nd}$ does not reveal any new behavior. The more dominant contribution of $\mathrm{Nd} 3 \mathrm{~d} 5 / 2-1$ to $998.9 \mathrm{eV}$ related to $\mathrm{Nd}(\mathrm{OH})_{3}$ is in equilibrium with the contribution to $977.9 \mathrm{eV}(\mathrm{Nd} 3 \mathrm{~d} 5 / 2-2)$ and refers to pure $\mathrm{Nd}_{2} \mathrm{O}_{3}$ (Figure $5 \mathrm{c}$ ). The ratio of the amounts of hydroxide and oxide phase remains unchanged. 

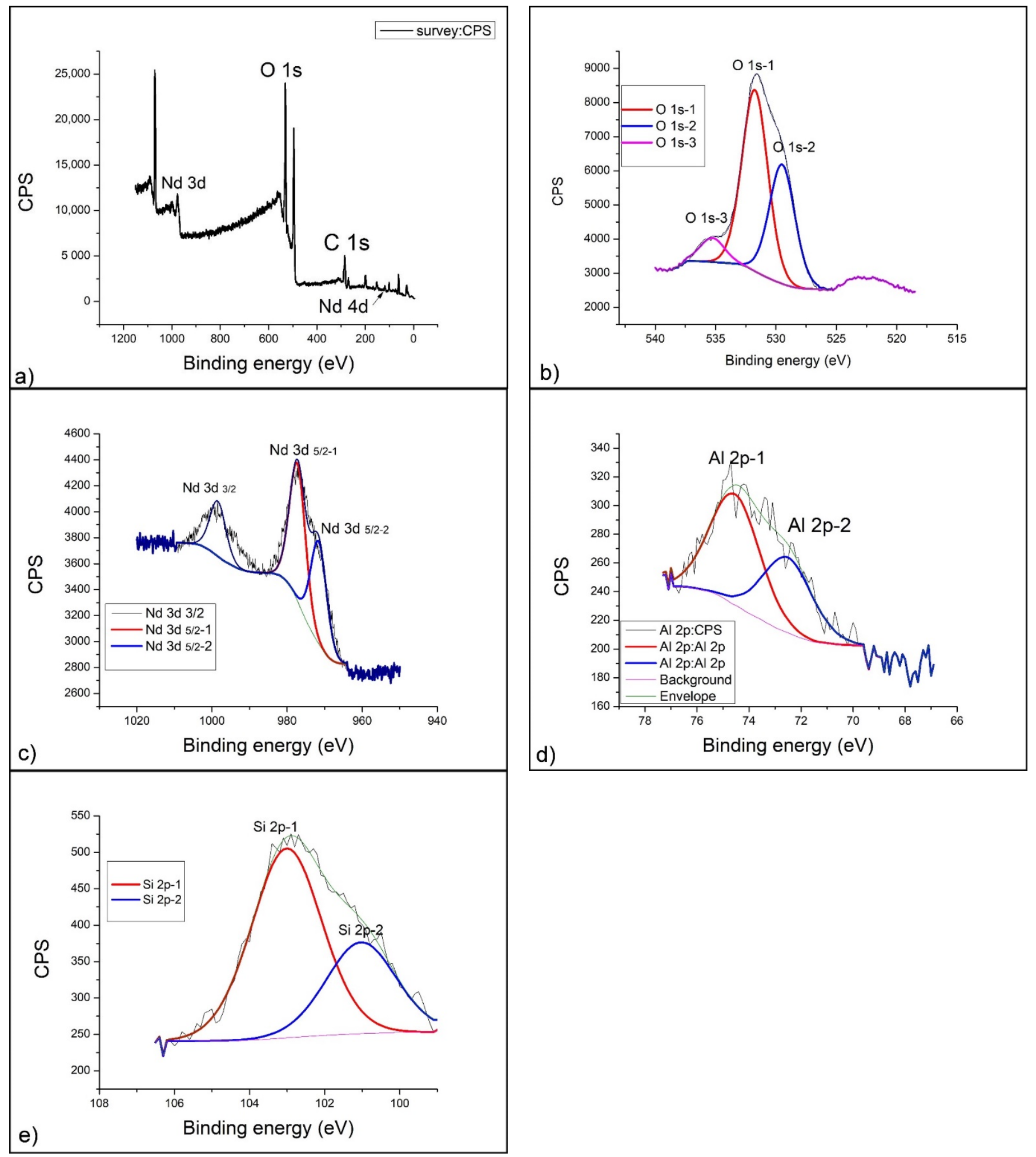

Figure 5. XPS spectrum of GP with 5\% Nd: (a) Survey spectrum, (b) O 1s, (c) Nd 3d, (d) Al 2p and (e) Si 2p.

A detailed analysis of the $\mathrm{Al} 2 \mathrm{p}$ spectral line shows a slight shift in the contribution to higher values of the binding energy (Figure $5 \mathrm{~d}$ ). The more dominant contribution of $\mathrm{Al} 2 \mathrm{p}-1$ at $74.6 \mathrm{eV}$ and the weaker contribution at $72.5 \mathrm{eV}$ refer, as in the previous case, to the amorphous and alpha crystalline phase [54]. The only thing that has changed is the ratio in the composition of these two phases, and it is 2:1. In the geopolymer sample with 
$5 \% \mathrm{Nd}$, the amount of the amorphous phase $\mathrm{Al}_{2} \mathrm{O}_{3}$ decreased, while the quantity of alpha crystalline phase remained almost unchanged (Figure 5e).

Figure 6a presents a survey spectrum of geopolymers with $1 \%$ added samarium. At first glance, it can be seen that the amount of carbon has been reduced, but the positioning of the energy axis has been performed without any problems. In the high-energy part of the spectrum over $1000 \mathrm{eV}$, the spectral line of Sm 3d is observed.

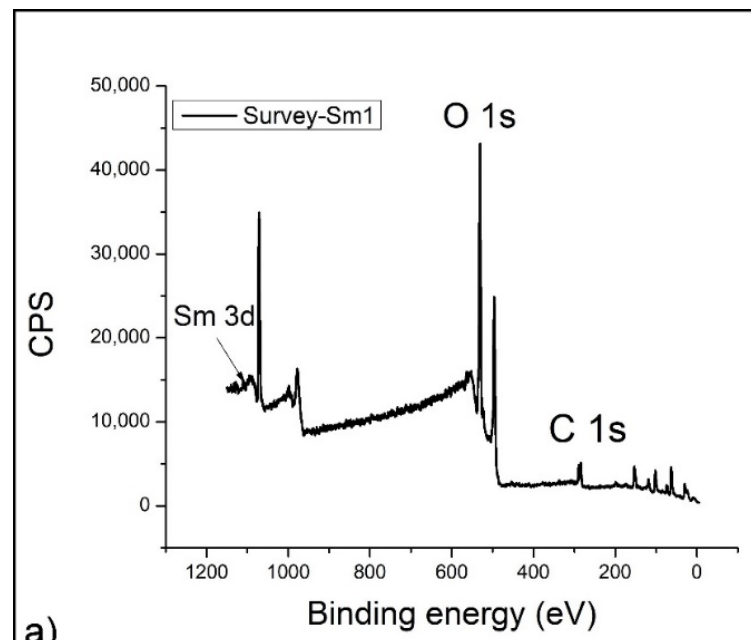

a)

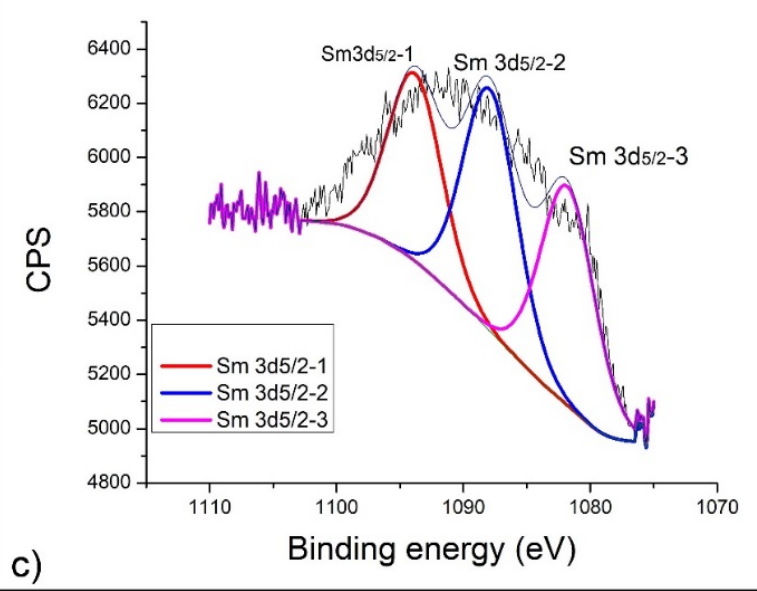

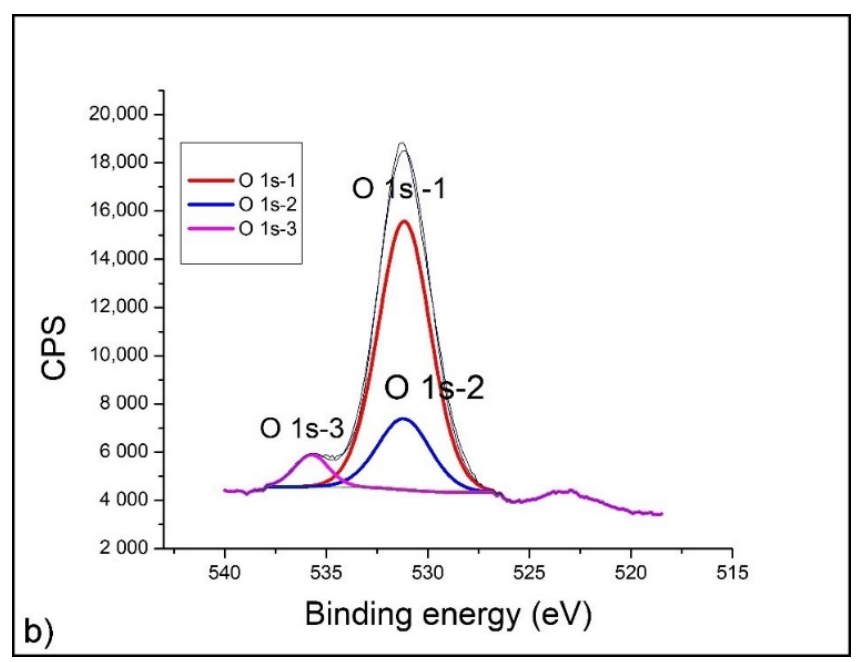

d)

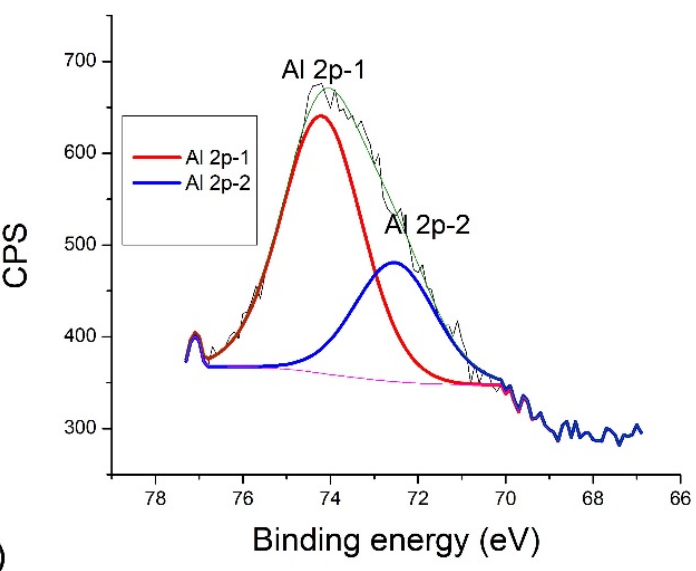

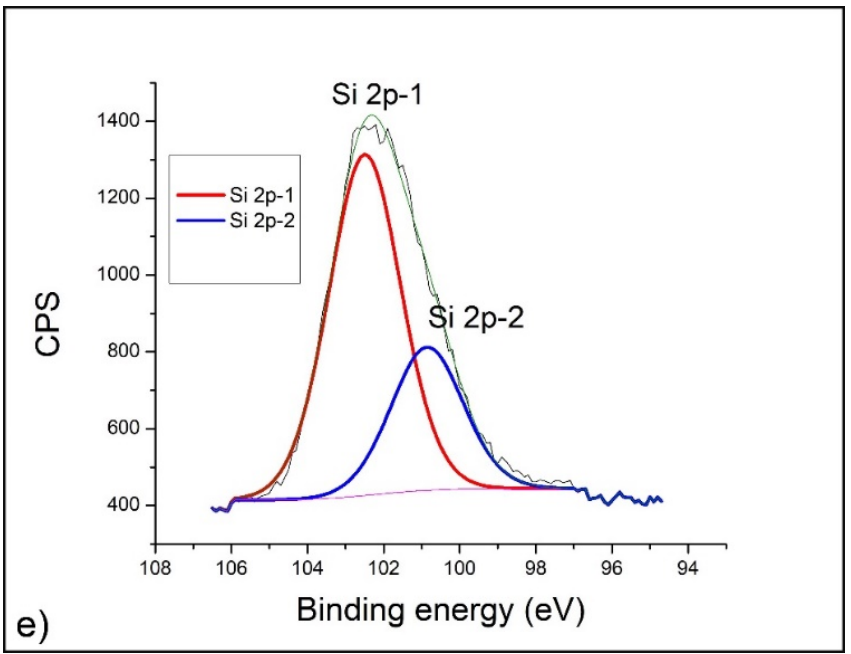

Figure 6. XPS spectrum of GP with 1\% Sm: (a) Survey spectrum, (b) O 1s, (c) Sm 3d, (d) Al 2p and (e) Si 2p. 
The position of the oxygen spectral line O1s -1 is at the expected place. Detailed analysis (Figure 6b) of this spectral line shows a dominant peak at $531.2 \mathrm{eV}$ corresponding to $\mathrm{Al}_{2} \mathrm{O}_{3}$. Similar to the other samples, the weaker peak at $535.7 \mathrm{eV}$ corresponds to $\mathrm{CaAl}_{2} \mathrm{O}_{4}$ and $\mathrm{SiAl}_{2} \mathrm{O}_{4}$. The ratio of amorphous to crystalline $\mathrm{Al}_{2} \mathrm{O}_{3}$ also remains unchanged and is $2: 1$.

Figure $6 \mathrm{c}$ represents the detailed spectrum of the $\mathrm{Sm} 3 \mathrm{~d}$ line. For the purposes of the analysis, only a $3 \mathrm{~d}_{5 / 2}$ spectral line was used, because it gives a complete insight into the behavior of $\mathrm{Sm}_{2} \mathrm{O}_{3}$ when it is affected by a strong base in the process of alkaline activation. Similar to GP with neodymium, samarium also shows a similar tendency to form an unstable hydroxide at a binding energy of $1088.1 \mathrm{eV}\left(\mathrm{Sm}_{2} \mathrm{O}_{3}+\mathrm{Sm}(\mathrm{OH})_{3}\right.$ mixture-Sm $\left.3 \mathrm{~d}_{5 / 2}-2\right)$ as well as the initial constituent $\mathrm{Sm}_{2} \mathrm{O}_{3}$ at $1081.9 \mathrm{eV}-\mathrm{Sm} 3 \mathrm{~d}_{5 / 2}-1$ [55].

Detailed spectra of Al 2p and Si 2p spectral lines (Figure 6d,e) indicate the formation of a complex geopolymer matrix of aluminosilicates. Thus, at a binding energy of $74.2 \mathrm{eV}$ (Figure $6 \mathrm{~d}$ ), the formation of a complex crystal hydrate of $\mathrm{Al}_{2} \mathrm{Si}_{2} \mathrm{O}_{7} \cdot 2 \mathrm{H}_{2} \mathrm{O}$ can be noticed with the existence of an amorphous phase of $\mathrm{Al}_{2} \mathrm{O}_{3}$, which is almost always present [56].

The aluminosilicate base of the geopolymer served as a good matrix for incorporation of rare earths ( $\mathrm{Nd}$ and $\mathrm{Sm}$ ), and XPS analysis showed that the behavior of these elements is similar in terms of alkaline activation but that neodymium is somewhat more sensitive to strong bases and more transformed into unstable hydroxide $\mathrm{Nd}(\mathrm{OH})_{3}$. Samarium (III) oxide $\left(\mathrm{Sm}_{2} \mathrm{O}_{3}\right)$ is therefore slightly less soluble in $12 \mathrm{M} \mathrm{NaOH}$ and, to a smaller extent, converted to hydroxide $\mathrm{Sm}(\mathrm{OH})_{3}$. The XPS spectral analysis provided full-insight chemical structure information of the Nd- and Sm-doped GP, as shown in Figures 4-6. The intensity of peaks corresponding to $\mathrm{Si}, \mathrm{O}$ and $\mathrm{Al}$ elements changed, indicating the transformation of chemical bond during the doping process. The intensification of $\mathrm{O}, \mathrm{Si}$, and $\mathrm{Al}$ peaks occurs mainly due to the geopolymerization of aluminosilicate. There are three types of primary chemical states of oxygen in geopolymer including $\mathrm{Si}-\mathrm{O}-\mathrm{Al}, \mathrm{Si}-\mathrm{O}-\mathrm{Si}$ and $\mathrm{Si}-\mathrm{O}-\mathrm{H}$, with the main spectral line positions at 531, 532 and $533 \mathrm{eV}$, according to the literature [57-59]. The fitted parameters of the O1 s XPS spectra are shown in Figures 4, 5 and $6 \mathrm{~b}$ for GPNd and GPSm, respectively. There are more Si-O-Al and Si-O-H chemical bonds in GPSm, which is in accordance with the FTIR results.

\subsection{TEM Analysis}

The geopolymer samples incorporated with $5 \%$ of $\mathrm{Nd}_{2} \mathrm{O}_{3}$ and $\mathrm{Sm}_{2} \mathrm{O}_{3}$ were additionally analyzed using transmission electron microscopy (TEM). The given images at magnification $11 \mathrm{kx}$ of both samples and X-ray energy dispersive spectrum (EDS) that is acquired on the same images are shown in Figures 7 and 8.

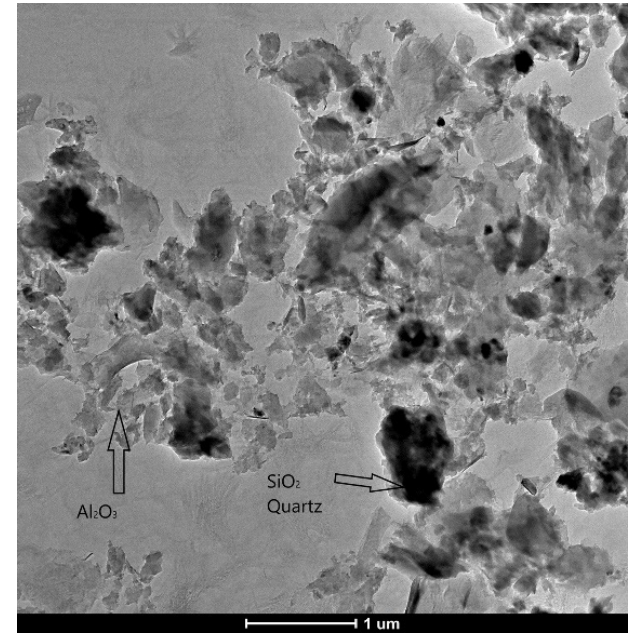

(a)

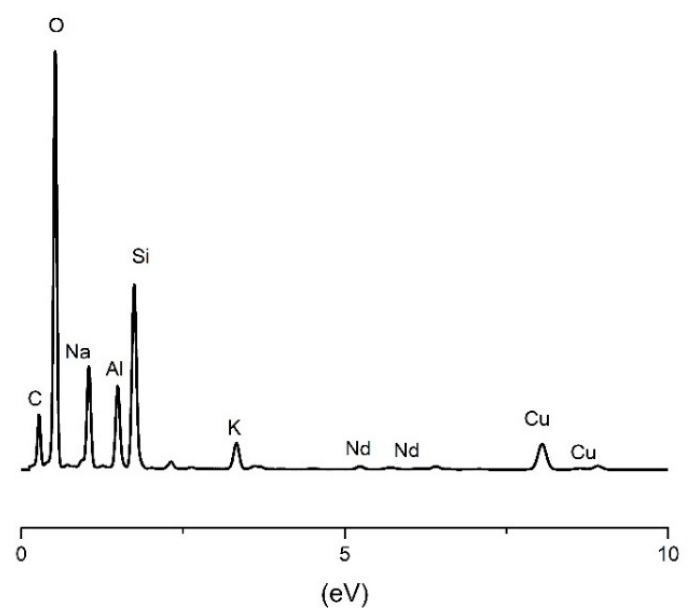

(b)

Figure 7. TEM analysis of geopolymer: (a) with $5 \% \mathrm{Nd}$; (b) corresponding EDS analysis. 


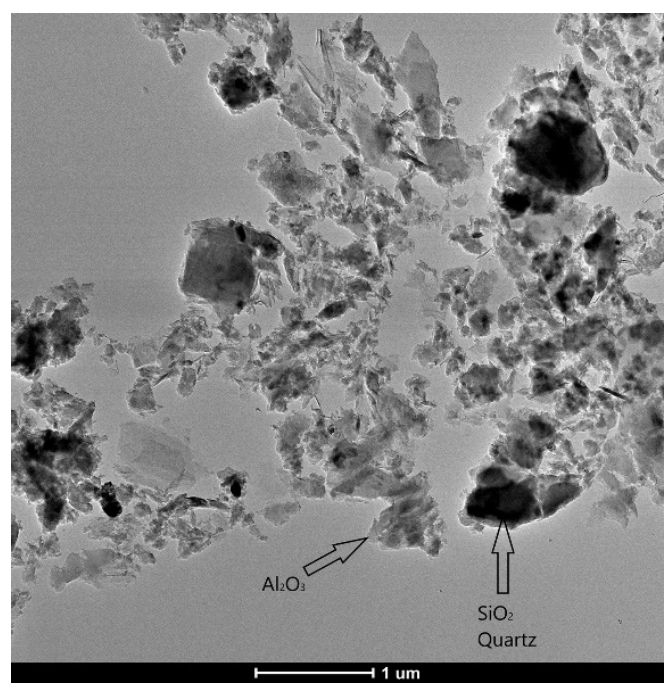

(a)

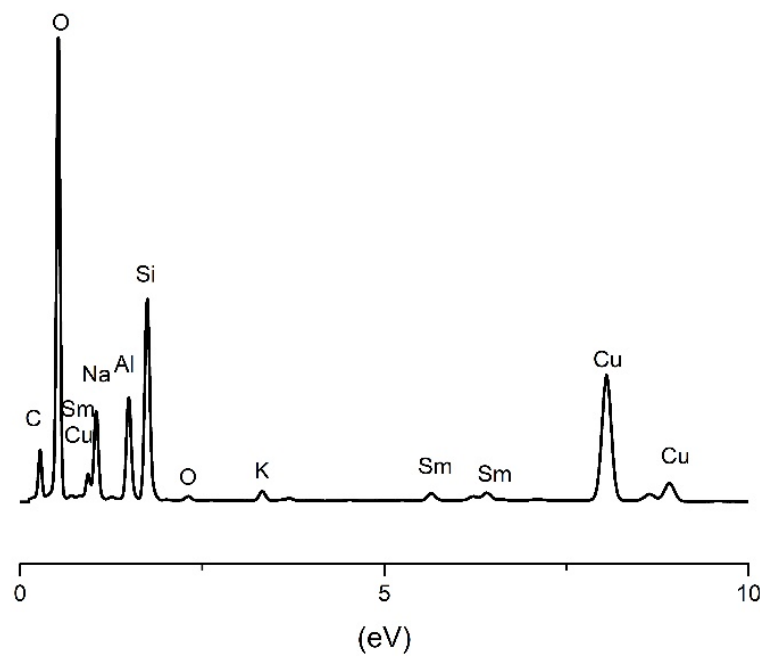

(b)

Figure 8. TEM analysis of geopolymer: (a) with 5\% Sm; (b) corresponding EDS analysis.

In Figure 7a, one can see the existence of two completely different phases, which are contrastingly divided as light and dark fields. Lighter-colored grains are primarily related to $\mathrm{Al}_{2} \mathrm{O}_{3}$. The dark grains in the image represent $\mathrm{SiO}_{2}$ in the form of quartz. Other zones, which are in different shades of gray, are a mixture of the most common phases as well as other aluminosilicate phases. Individual grains are in the range of 50 to $100 \mathrm{~nm}$, but due to the occurrence of aggregation, they form larger grains of about $500 \mathrm{~nm}$. The presence of $\mathrm{Nd}$ as a dopant can be confirmed by EDS analysis (Figure $7 \mathrm{~b}$ ), where alpha and beta lines appear in the middle of the energy axis. By structural analysis, we can achieve a clear insight into the incorporation of $\mathrm{Nd}$ as a dopant. It partly entered the structure but partly remained as a separate phase at the grain boundaries.

The situation is similar with geopolymers doped with $5 \% \mathrm{Sm}$ (Figure 8a). A clear division into light and dark fields indicates the existence of $\mathrm{Al}_{2} \mathrm{O}_{3}$ and $\mathrm{SiO}_{2}$ (quartz). The separation of the phase of neodymium and samarium oxides can be explained by insufficient reactivity and the absence of thermodynamic parameters for all $\mathrm{Nd}^{3+}$ and $\mathrm{Sm}^{3+}$ ions to be incorporated into the geopolymer structure. The partial ion change occurred, but the solid solution was not completely formed. Comparing these results with the XPS results, we can conclude that we have two dominant phases of $\mathrm{Nd}$ and Sm that chemically belong to hydroxides $\mathrm{Nd}(\mathrm{OH})_{3}$ and $\mathrm{Sm}(\mathrm{OH})_{3}$ and oxides as the starting dopant.

The particle size presented in Figure 8a shows a wide distribution from smaller grains to larger clusters. This behavior is a consequence of the reaction path that leads to the final product. The reaction in a solution in which a strong base is present leads to the typical micro-nano structures that are formed. Smaller particles that are initially formed combine with larger ones in the process of geopolymerization and coalesce into larger crystals that are multiphase. In this way, $\mathrm{Nd}^{3+}$ and $\mathrm{Sm}^{3+}$ ions, whose ionic radius is much larger than the ionic radius $\mathrm{Al}$ and $\mathrm{Si}$, have a high resistance to entering the aluminosilicate lattice [60] and are only partially incorporated, while they are distributed thermodynamically more stable at the grain boundaries. Partially dissolved aluminosilicates in a concentrated alkaline medium form an amorphous geopolymeric gel incorporated with undissolved crystalline particles. Some aluminosilicates dissolve preferentially to form an equilibrium ratio of aluminum to silicon in the gel. As a consequence, the gel phases formed during the geopolymerization of the kaolinite, $\mathrm{Nd}$ and $\mathrm{Sm}$ are probably amorphous to semicrystalline in structure. This may be due to the varied $\mathrm{Si} / \mathrm{Al}$ ratio of raw material and different polymerization conditions [61,62]. On both TEM images (Figures 7a and 8a), formed gels have a relatively consistent shape and size of primary particles with neodymium and samarium, respectively. The particle size is slightly larger in GPSm (Figure 8a), about 
15-20 nm larger compared to GPNd (Figure 7a). Phair et al. report particles in the order of $10 \mathrm{~nm}$ in diameter for all compositions of similar aluminosilicate gels studied, also noting a slight increase in particle size as sodium concentration increases [63]. Chen and Mondal observed gel particle size to increase and appear smoother and rounder with the addition of $\mathrm{NaOH}$ [64]. Here the difference of sodium content between gels is not so significant, but particles with higher sodium concentrations are larger and smoother.

\section{Conclusions}

The incorporation of neodymium and samarium ions into the geopolymer matrix was the aim of this research. A better doping effect was achieved with a concentration of $5 \mathrm{wt} . \%$ than with $1 \mathrm{wt} . \%$. This innovative process has shown that there are certain structural and chemical changes in the geopolymer matrix. Trivalent $\mathrm{Nd}^{3+}$ and $\mathrm{Sm}^{3+}$ ions, which formed a nonequilibrium charge in GP, formed Nd-O and Sm-O bonds confirmed by the DRIFT method, where the structural change in the geopolymer aluminosilicate matrix occurred. The phase composition of the newly obtained composite gel confirmed the existence of two dominant phases of neodymium and samarium in GP. They were mutually confirmed by XRD and XPS methods, where the starting oxide and unstable hydroxide were detected in equilibrium. The rest of the dominant phase is the aluminosilicate matrix of GP with a variable Al-to-Si ratio in the system. Transmission microscopy revealed an even clearer insight into the micronano structure of the resulting gel composite. Smaller crystallites coalesce into larger grains under the influence of a strong base in the geopolymerization process, two different phases of $\mathrm{Al}_{2} \mathrm{O}_{3}$ and $\mathrm{SiO}_{2}$ (quartz) are clearly visible, while $\mathrm{Nd}$ and $\mathrm{Sm}$ precipitates have separated at the grain boundaries.

\section{Materials and Methods}

\subsection{Materials}

Geopolymer gels were produced by reaction of metakaolin described by Nenadović et al., 2017 [31] with a sodium silicate-activating solution. The activating solutions were prepared by dissolving $12 \mathrm{M}$ sodium hydroxide powder (Sigma-Aldrich, St. Louis, MO, USA, analytical grade) and sodium silicate (technical grade) in appropriate ratio (volume ratio $\mathrm{Na}_{2} \mathrm{SiO}_{3} / \mathrm{NaOH}=1.5$ ).

Commercially available $\mathrm{Nd}_{2} \mathrm{O}_{3}$ (Acros Organics, Geel, Belgium, 99.9\%) and $\mathrm{Sm}_{2} \mathrm{O}_{3}$ (Merck KGaA, Darmstadt, Germany, 99+) powder was mixed during process of geopolymerization in geopolymer paste. The two weight fractions of both of these oxides $(1 \%$ and $5 \%$ ) were used in process of preparation of geopolymer samples. Metakaolin $/ \mathrm{Nd}_{2} \mathrm{O}_{3}$, $\mathrm{Sm}_{2} \mathrm{O}_{3}$ and the alkaline solution (solid/liquid ratio was 1.0) were mixed for $15 \mathrm{~min}$ and then left at room temperature for one day. After that, the mixture was kept at $60{ }^{\circ} \mathrm{C}$ for additional two days in appropriate covered molds and subsequently aged at room temperature in controlled conditions for 28 days.

\subsection{Methods and Characterization}

- Thermodynamic parameters of activating solution were examined. Using the Anton Paar DSA $5000 \mathrm{M}$ digital densitometer, the density as well as the speed of sound were measured. The range of density measurements on this device is from 0 to $3 \times 10^{-3}$ $\mathrm{kgm}^{-3}$, and the speed of sound is from 1000 to $2000 \mathrm{~m} \mathrm{~s}^{-1}$. Experimental measurement of refractive index was performed on an automatic refractometer (model Anton Paar RXA 156), which operates at a wavelength of $589 \mathrm{~nm}$. The device has a built-in thermostat with an accuracy of $\pm 0.03 \mathrm{~K}$ by which the temperature of the samples is kept constant during the measurement. The measurement range of the refractive index is from 1.32 to 1.56 . For all thermodynamics parameters, all measurements were performed in the temperature range from $288.15 \mathrm{~K}$ to $333.15 \mathrm{~K}$.

- Diffuse reflectance infrared Fourier transform spectroscopy (DRIFTS) is a cheap, fast and nondestructive way of evaluating clay minerals and their products [25]. Drift spectra were obtained using the Perkin-Elmer FTIR spectrometer. Approximately 5\% 
samples were dispersed in oven-dried spectroscopic grade $\mathrm{KBr}$ with the refractive index of 1.559 and particle size of $5-20 \mu \mathrm{m}$.

Background $\mathrm{KBr}$ spectra were obtained and spectra were rationed to the background. The spectra were scanned at $4 \mathrm{~cm}^{-1}$ resolution and collected in the mid-IR region from 4000 to $400 \mathrm{~cm}^{-1}$.

- $\quad$ XRD measurements were conducted at room temperature using Ultima IV Rigaku diffractometer, equipped with $\mathrm{CuK} \alpha 1,2$ radiation, using a generator voltage $(40.0 \mathrm{kV})$ and a generator current $(40.0 \mathrm{~mA})$. The range of $5-80^{\circ} 2 \theta$ was used for all powders in a continuous scan mode with a scanning step size of $0.02^{\circ}$ and at a scan rate of $5^{\circ} / \mathrm{min}$ using $\mathrm{D} / \mathrm{TeX}$ Ultrahigh-speed detector. Samples were crushed in the in a porcelain mortar to the fineness of a fine powder. Si-monocrystalline sample carrier was used. The PDXL2 (Ver. 2.8.4.0) software was used to evaluate the phase identification and microstructure properties of material $[62,63]$. All obtained powders were identified using the ICDD data base [64]. For phase identification, selected PDF card numbers were used: Quartz $\left(\mathrm{SiO}_{2} ; 01-079-6237\right)$, Albite $\left(\mathrm{Na}\left(\mathrm{AlSi}_{3} \mathrm{O}_{8}\right) ; 01-084-\right.$ 0982), Muscovite $\left(\mathrm{KAl}_{2}(\mathrm{Si}, \mathrm{Al})_{4} \mathrm{O}_{10}(\mathrm{OH})_{2} ; 00-058-2036\right)$, Samarium Oxide $\left(\mathrm{Sm}_{2} \mathrm{O}_{3}\right.$; 00-042-1464), Neodymium Hydroxide $\left.\mathrm{Nd}(\mathrm{OH})_{3}, 01-070-0214\right)$ and Neodymium oxide $\left(\mathrm{Nd}_{2} \mathrm{O}_{3}, 00-006-0408\right)$.

- XPS analysis was performed using a SPECS instrument for detailed chemical composition characterization using X-ray-induced photoelectron spectroscopy. More detailed explanation can be found in Nenadovic et al., 2017 [31] and Ivanovic et al., 2020 [33]. Photoelectron emission was excited by monochromatic $\mathrm{Al} \mathrm{K} \alpha$ line with photon energy of $1486.67 \mathrm{eV}$. Detailed spectra of the main photoelectron lines were taken in the fixed analyzer transmission mode with a pass energy of $20 \mathrm{eV}$ (FAT 20), an energy step of $0.1 \mathrm{eV}$ and a dwell time of $2 \mathrm{~s}$. Charging compensation was performed using an electron flood gun and the constant current and voltage. The binding energy axis was adjusted according to the position of the carbon $C$ 1s line. The survey spectra were performed according to the characteristic spectral line intensities. Specific atomic sensitivity factors for each analyzed element were used to eliminate the background lines, provided by the manufacturer. The photoelectron lines were fitted to peaks using appropriate software package.

- Characterization and investigation of the micronano samples structure was carried out by TEM, using a FEI Talos F200X microscope operating at $200 \mathrm{keV}$. A CCD camera with a resolution of $4096 \times 4096$ pixels was used for acquiring micrographs using the User Interface software package. The geopolymer samples were also further analyzed using scanning transmission (STEM) mode with energy dispersive spectrometry (EDS). The EDS detection system was used to determine the presence of doping species of $\mathrm{Nd}$ and Sm in geopolymer matrix. High-angle annular dark-field (HAADF) imaging was used in nanoprobe-TEM mode with a camera length of $\sim 200 \mathrm{~nm}$ using the standard annular dark-field detector. The powder samples were prepared by standard rinsing and diluting in ethanol to a sufficient concentration to trap the geopolymer powder on the TEM grid, dried in air and then transferred to microscope.

Author Contributions: S.S.S.N. and M.T.N. conceptualized the research, designed and prepared the research plan, synthesized the samples and wrote and revised the manuscript. L.M.K. synthesized the samples, wrote part of the manuscript and analyzed obtained results. M.M.M. contributed in the analysis and discussion of the XRD results. L.Z.R. and M.T.N. also performed XPS analysis and discussion of obtained results. M.M.I. characterized thermodynamical parameters of the alkali activator system and, together with S.S.S.N., completed DRIFT analysis. N.R. performed TEM analysis of all samples. All the authors contributed to the literature research, data analysis and the preparation of the manuscript. All authors have read and agreed to the published version of the manuscript.

Funding: This research received no external funding. 
Institutional Review Board Statement: This research does not involve humans or animals.

Informed Consent Statement: This research does not involve humans.

Data Availability Statement: We exclude this statement because we don't have any data.

Acknowledgments: This work was financially supported by the Ministry of Education, Science and Technological Development of Republic of Serbia on the research program grant No. 0402105 and grant No. 1702102, Vinča Institute of Nuclear Sciences, National Institute of the Republic of Serbia, University of Belgrade, Serbia.

Conflicts of Interest: The authors declare no conflict of interest.

\section{References}

1. Song, H.; Wei, L.; Ji, Y.; Cao, L.; Cheng, F. Heavy metal fixing and heat resistance abilities of coal fly ash-waste glass based geopolymers by hydrothermal hot pressing. Adv. Powder Technol. 2018, 29, 1487-1492. [CrossRef]

2. Siyal, A.A.; Shamsuddin, M.R.; Khan, M.I.; Rabat, N.E.; Zulfiqar, M.; Man, Z.; Siame, J.; Azizli, K.A. A review on geopolymers as emerging materials for the adsorption of heavy metals and dyes. J. Environ. Manag. 2018, 224, 327-339. [CrossRef]

3. Fernández-Jiménez, A.; Palomo, A.; Macphee, D.E.; Lachowski, E.E. Fixing Arsenic in Alkali-Activated Cementitious Matrices. J. Am. Ceram. Soc. 2005, 88, 1122-1126. [CrossRef]

4. Van Jaarsveld, J.G.S.; Van Deventer, J.S.J.; Schwartzman, A. The potential use of geopolymeric materials to immobilise toxic metals: Part II. Material and leaching characteristics. Miner. Eng. 1999, 12, 75-91. [CrossRef]

5. Singh, N.B.; Middendorf, B. Geopolymers as an alternative to Portland cement: An overview. Constr. Build. Mater. 2020, 237, 117455. [CrossRef]

6. Palomo, A.; López dela Fuente, J.I. Alkali-activated cementitous materials: Alternative matrices for the immobilisation of hazardous wastes: Part I. Stabilisation of boron. Cem. Concr. Res. 2003, 33, 281-288. [CrossRef]

7. Bankowski, P.; Zou, L.; Hodges, R. Reduction of metal leaching in brown coal fly ash using geopolymers. J. Hazard. Mater. 2004, 114, 59-67. [CrossRef] [PubMed]

8. Fernandez-Jimenez, A.; Macphee, D.E.; Lachowski, E.E.; Palomo, A. Immobilization of cesium in alkaline activated fly ash matrix. J. Nucl. Mater. 2005, 346, 185-193. [CrossRef]

9. Mladenović, N.; Kljajević, L.; Nenadović, S.; Ivanović, M.; Čalija, B.; Gulicovski, J.; Trivunac, K. The Applications of New Inorganic Polymer for Adsorption Cadmium from Waste Water. J. Inorg. Organomet. Polym. Mater. 2020, 30, 554-563. [CrossRef]

10. Yu, L.; Fang, L.; Zhang, P.; Zhao, S.; Jiao, B.; Li, D. The Utilization of Alkali-Activated Lead-Zinc Smelting Slag for Chromite Ore Processing Residue Solidification/Stabilization. Int. J. Environ. Res. Public Health 2021, 18, 9960. [CrossRef]

11. Narasimharao, K.; Ali, T.T. Influence of synthesis conditions on physico-chemical and photocatalytic properties of rare earth (Ho, $\mathrm{Nd}$ and Sm) oxides. J. Mater. Res. Technol. 2020, 9, 1819-1830. [CrossRef]

12. Trivunac, K.; Ljiljana, K.; Snežana, N.; Jelena, G.; Miljana, M.; Biljana, B.; Slavica, S. Microstructural characterization and adsorption properties of alkali-activated materials based on metakaolin. Sci. Sinter. 2016, 48, 209-220. [CrossRef]

13. Volokh, A.A.; Gorbunov, A.V.; Gundorina, S.F.; Revich, B.A.; Frontasyeva, M.V.; Pal, C.S. Phosphorus fertilizer production as a source of rare-earth elements pollution of the environment. Sci. Total Environ. 1990, 95, 141-148. [CrossRef]

14. Parnicka, P.; Mazierski, P.; Grzyb, T.; Lisowski, W.; Kowalska, E.; Ohtani, B.; Zaleska-Medynska, A.; Nadolna, J. Influence of the preparation method on the photocatalytic activity of $\mathrm{Nd}-$ Modified $\mathrm{TiO}_{2}$. Beilstein J. Nanotechnol. 2018, 9, 447-459. [CrossRef]

15. Reszczyńska, J.; Grzyb, T.; Sobczak, J.W.; Lisowski, W.; Gazda, M.; Ohtani, B.; Zaleska, A. Visible light activity of rare earth metal doped $\left(\mathrm{Er}^{3+}, \mathrm{Yb}^{3+}\right.$ or $\left.\mathrm{Er}^{3+} / \mathrm{Yb}^{3+}\right)$ titania photocatalysts. Appl. Catal. B Environ. 2015, 163, 40-49. [CrossRef]

16. Bachvarova-Nedelcheva, A.; Yordanov, S.; Iordanova, R.; Stambolova, I.; Stoyanova, A.; Georgieva, N.; Nemska, V. The Influence of $\mathrm{Nd}$ and $\mathrm{Sm}$ on the Structure and Properties of Sol-Gel-Derived $\mathrm{TiO}_{2}$ Powders. Molecules 2021, 26, 3824. [CrossRef] [PubMed]

17. Stengl, V.; Bakardjieva, S.; Murafa, N. Preparation and photocatalytic activity of rare earth-doped $\mathrm{TiO}_{2}$ nanoparticles. Mater. Chem. Phys. 2009, 114, 217-226. [CrossRef]

18. Dinkar, A.V.; Shridhar, J.S.; Madhukar, E.N.; Anil, A.; Nitin, K. Sm-Doped $\mathrm{TiO}_{2}$ Nanoparticles with High Photocatalytic Activity For ARS Dye Under Visible Light Synthesized by Ultrasonic Assisted Sol-Gel Method. Orient. J. Chem. 2016, 32, 933-940. [CrossRef]

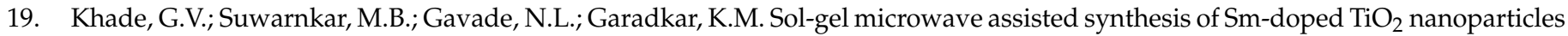
and their photocatalytic activity for the degradation of Methyl Orange under sunlight. J. Mater. Sci. Mater. Electr. 2016, 27, 6425-6432. [CrossRef]

20. Shehata, N.; Meehan, K. Potential applications of samarium as a dopant element. In Samarium: Chemical Properties, Occurrence and Potential Applications; Kaitlyn, R., Ed.; Danford Nova Publisher: New York, NY, USA, 2014; pp. 111-136.

21. Kirdsiri, K.; Rajaramakrishnab, R.; Damdeea, B.; Kimc, H.J.; Kimc, H.J.; Horphathumd, M.; Kaewkhao, J. Influence of alkaline earth oxides on $\mathrm{Eu}^{3+}$ doped lithium borate glasses for photonic, laser and radiation detection material applications. Solid State Sci. 2019, 89, 57-66. [CrossRef]

22. Gaafara, M.S.; Marzouk, S.Y.; Mahmouda, I.S.; Henda, M.B.; Afifi, M.; Ahmed, M.; El-Aziz, A.M.A.; Alhabradi, M. Role of Neodymium on Some Acoustic and PhysicalProperties of $\mathrm{Bi}_{2} \mathrm{O}_{3}-\mathrm{B}_{2} \mathrm{O}_{3}$ - SrO Glasses. J. Mater. Res. 2020, 9, $7252-7261$. 
23. Thomas, P.J.; Carpenter, D.; Boutin, C.; Allison, J.E. Rare earth elements (REEs): Effects on germination and growth of selected crop and native plant species. Chemosphere 2014, 96, 57-66. [CrossRef]

24. Yang, Q.; Wang, L.; Zhou, Q.; Huang, X. Toxic effects of heavy metal terbium ion on the composition and functions of cell membrane in horseradish roots. Ecotoxicol. Environ. Saf. 2015, 111, 48-58. [CrossRef] [PubMed]

25. Sneller, F.E.C.; Kalf, D.F.; Weltje, L.; Van Wezel, A.P. Maximum Permissible Concentrations and Negligible Concentrations for Rare Earth Elements (REEs))., RIVM Report 601501 011; National Institute of Public Health and the Environment: Amsterdam, The Netherlands, 2000; p. 44.

26. Slooff, W.; Bont, P.F.H.; van den Hoop, M.A.G.T.; Janus, A.; Annema, J.A. Exploratory Report: Rare Earth Metals and Their Compounds; National Institute of Public Health and Environmental Protection: Bilthoven, The Netherlands, 1993.

27. Pickard, B.G. Comparison of Calcium and Lanthanon Ions in the Avena-Coleoptile Growth Test. Planta 1970, 91, 314-320. [CrossRef]

28. Hu, Z.; Richter, H.; Sparovek, G.; Schnug, E. Physiological and Biochemical Effects of Rare Earth Elements on Plants and Their Agricultural Significance: A Review. J. Plant Nutr. 2004, 27, 183-220. [CrossRef]

29. Xiaoqing, L.; Hao, H.; Chao, L.; Min, Z.; Fashui, H. Physico-chemical property of rare earths-effects on the energy regulation of photosystem II in Arabidopsis thaliana. Biol. Trace Elem. Res. 2009, 130, 141-151. [CrossRef]

30. Ivanović, M.; Nenadović, S.; Pavlović, V.P.; Radović, I.; Kijevčanin, M.; Pavlović, V.B.; Kljajević, L. The influence of thermodynamic parameters on alkaline activators of geopolymers and the structure of geopolymers. Maced. J. Chem. Chem. Eng. 2021, 40, 107-117. [CrossRef]

31. Nenadović, S.S.; Kljajević, L.M.; Nešić, M.A.; Petković, M.Z.; Trivunac, K.V.; Pavlović, V.B. Structure analysis of geopolymers synthesized from clay originated from Serbia. Environ. Earth Sci. 2017, 76, 79. [CrossRef]

32. Kljajević, L.M.; Nenadović, S.S.; Nenadović, M.T.; Bundaleski, N.K.; Todorović, B.Ž.; Pavlović, V.B.; Rakočević, Z.L. Structural and chemical properties of thermally treated geopolymer samples. Ceram. Int. 2017, 43, 6700-6708. [CrossRef]

33. Ivanović, M.; Ljiljana, K.; Jelena, G.; Marijana, P.; Ivona, J.-C.; Dušan, B.; Snežana, N. The Effect of the Concentration of Alkaline Activator and Aging Time on the Structure of Metakaolin Based Geopolymer. Sci. Sinter. 2020, 52, 219-229. [CrossRef]

34. Hajimohammadi, H.; Provis, J.L.; van Deventer, J.S.J. The effect of silica availability on the mechanism of geopolymerisation. Cem. Concr. Res. 2011, 41, 210-216. [CrossRef]

35. Provis, J.L.; Bernal, S.A. Geopolymers and Related Alkali-Activated Materials. Annu. Rev. Mater. Res. 2014, 44, 299-327. [CrossRef]

36. Perumal, P.; Kiventerä, J.; Illikainen, M. Influence of alkali source on properties of alkali activated silicate tailings. Mater. Chem. Phys. 2021, 271, 124932. [CrossRef]

37. Nenadovic, M.; Ferone, C.; Kljajević, L.; Miljana, M.; Todorović, B.; Vukanac, I.; Nenadović, S. Alkali Activation of Different type of ash as a production of combustion proces. Nucl. Technol. Radiat. Prot. 2021, 36, 66-73. [CrossRef]

38. Kljajević, L.M.; Melichová, Z.; Kisić, D.; Nenadović, M.; Todorović, B.Ž.; Pavlović, V.B.; Nenadović, S. The influence of aluminosilicate matrix composition on surface hydrophobic properties. Sci. Sinter. 2019, 51, 163-173. [CrossRef]

39. Lee, W.K.W.; van Deventer, J.S.J. Use of Infrared Spectroscopy to Study Geopolymerization of Heterogeneous Amorphous Aluminosilicates. Langmuir 2003, 19, 8726-8734. [CrossRef]

40. Rees, C.A.; Provis, J.L.; Lukey, G.C.; van Deventer, J.S.J. Attenuated Total Reflectance Fourier Transform Infrared Analysis of Fly Ash Geopolymer Gel Aging. Langmuir 2007, 23, 8170-8179. [CrossRef]

41. Nenadovic, S.; Kljajević, L.; Marković, S.; Omerašević, M.; Jovanovic, U.; Andric, V.; Vukanac, I. Natural diatomite (Rudovci, Seria) as adsorbent for removal Cs from radioactivite waste liquids. Sci. Sinter. 2015, 47, 299-309. [CrossRef]

42. Nenadović, S.; Nenadović, M.; Vukanac, I.; Đorđević, A.; Dragićević, S.; Lješević, M. Vertical distribution of 137Cs in cultivated and undisturbed areas. Nucl. Technol. Radiat. Prot. 2010, 25, 30-36. [CrossRef]

43. Zhao, Y.; Kang, S.; Qin, L.; Wang, W.; Zhang, T.; Song, S.; Komarneni, S. Self-assembled gels of Fe-chitosan/montmorillonite nanosheets: Dye degradation by the synergistic effect of adsorption and photo-Fenton reaction. Chem. Eng. J. 2020, 379. [CrossRef]

44. Gulicovski, J.; Nenadovic, S.; Kljajevic, L.; Mirkovic, M.; Nisavic, M.; Kragovic, M.; Stojmenovic, M. Geopolymer/CeO 2 as solid electrolity for IT-SOFC. Polymers 2020, 12, 248. [CrossRef]

45. Wang, W.; Zhao, Y.; Bai, H.; Zhang, T.; Ibarra-Galvan, V.; Song, S. Methylene blue removal from water using the hydrogel beads of poly(vinyl alcohol)-sodium alginate-chitosan-montmorillonite. Carbohydr. Polym. 2018, 198, 518-528. [CrossRef]

46. Peyne, J.; Gautron, J.; Doudeau, J.; Joussein, E.; Rossignol, S. Influence of calcium addition on calcined brick clay based geopolymers: A thermal and FTIR spectroscopy study. Constr. Build. Mater. 2017, 152, 794-803. [CrossRef]

47. Zhang, T.; Zhao, Y.; Kang, S.; Li, Y.; Zhang, Q. Formation of active $\mathrm{Fe}(\mathrm{OH})_{3}$ in situ for enhancing arsenic removal from water by the oxidation of $\mathrm{Fe}$ (II)in air with the presence of $\mathrm{CaCO}_{3}$. J. Clean. Prod. 2019, 227, 1-9. [CrossRef]

48. Hu, H.; Zhang, Q. Mechanochemical Preparation of Mineral Based Adsorbent and Its Effective Purification Ability for Wastewater. KONA Powder Part. J. 2021, 38, 155-167. [CrossRef]

49. Yuvakkumar, R.; Hong, S.I. $\mathrm{Nd}_{2} \mathrm{O}_{3}$ : Novel synthesis and characterization. J. Sol-Gel Sci. Technol. 2015, 73, 511-517. [CrossRef]

50. Suzuki, S.; Saito, H.; Yubuta, K.; Oishi, S.; Teshima, K. Growth of Millimeter-sized Platy Single Crystals of $\mathrm{NaTaO}_{3}$ from $\mathrm{Na}_{2} \mathrm{MoO}_{4}$ Flux. Cryst. Growth Des. 2019, 19, 3607-3611. [CrossRef]

51. Hu, S.; Zhong, L.; Yang, X.; Bai, H.; Ren, B.; Zhao, Y.; Zhang, W.; Ju, X.; Wen, H.; Mao, S.; et al. Synthesis of rare earth tailing-based geopolymer for efficiently immobilizing heavy metals. Constr. Build. Mater. 2020, 254, 119273. [CrossRef] 
52. Deepa, A.V.; Priya, M.; Suresh, S.R. Influence of Samarium Oxide ions on structural and optical properties of borate glasses. Sci. Res. Essays 2016, 11, 57-63. [CrossRef]

53. Sarma, D.D.; Rao, C.N.R. XPES studies of oxides of second- and third-row transition metals including rare earths. J. Electron Spectrosc. Relat. Phenom. 1980, 20, 25-45. [CrossRef]

54. Turner, N.H.; Single, A.M. Determination of peak positions and areas from wide-scan XPS spectra. Surf. Interface Anal. 1990, 15, 215-222. [CrossRef]

55. Aarnink, W.A.M.; Weishaupt, A.; van Silfhout, A. Angle-resolved X-ray photoelectron spectroscopy (ARXPS) and a modified Levenberg-Marquardt fit procedure: A new combination for modeling thin layers. Appl. Surf. Sci. 1990, 45, 37-48. [CrossRef]

56. Uwamino, Y.; Ishizuka, T.; Yamatera, H. X-ray photoelectron spectroscopy of rare-earth compounds. J. Electron Spectrosc. Relat. Phenom. 1984, 34, 67-78. [CrossRef]

57. Simonsen, M.E.; Sondebry, C.; Li., Z.; Sogard, E.G. XPS and FT-IR investigation of silicate polymers. J. Mater. 2009, 44, 2079-2088. [CrossRef]

58. Jhang, J.H.; Boscoboinik, J.A.; Altman, E.I. Ambient pressure X-ray photoelectron spectroscopy study of water formation and adsortption under two-dimesional silica and aluminosilicate layers on Pd (III). J. Chem. Phys. 2020, 152, 084705. [CrossRef] [PubMed]

59. Revathi, T.; Jeyalakshmi, R. XPS, 29Si, 27Al, 11B MAS -NMR, ATR-IR and FESEM characterization of geopolymer based on borax modified water glass activated Fly ash-GGBS blend. Mater. Res. Express 2019, 6, 085337. [CrossRef]

60. Rigaku. PDXL Integrated X-ray Powder Diffraction Softvare, 2.8.3.0; Rigaku: Tokyo, Japan, 2011.

61. Xiaohong, Z.; Chengying, B.; Yingjie, Q.; Xiadong, W.; Decland, J.; Hongqiang, L.; Paolo, C. Porous geopolymer composites A review. Compos. Part A 2021, 150, 106629. [CrossRef]

62. Phair, J.W.; Schulz, J.C.; Aldridge, L.P.; Smith, J.D. Small-angle neutron scattering and rheological characterization of aluminosilicate hydrogels. J. Am. Ceram. Soc. 2004, 87, 129-137. [CrossRef]

63. Sellami, M.; Barre, M.; Toumi, M. Synthesis, thermal properties and electrical conductivity of phosphoric acid-based geopolymer with metakaolin. Appl. Clay Sci. 2019, 180, 105192. [CrossRef]

64. IC Database. N.S. 12 Campus Blvd; IC Database: Philadelphia, PA, USA, 2012; p. 19073. 